\title{
EFFECTS OF CHOLINE ON THE LEUCOCYTE PICTURE AND ON THE SERUM CHOLINESTERASE ACTIVITY IN RABBITS
}

\author{
SHOICHI IIDA AND SHUNJI TAMURA \\ Defartment of Plarmacology, Faculty of Medicine, Hokkaido University, Sapporo \\ Received for publication December 20, 1954
}

\section{INTRODUCTION}

In 1906, Werner and Lichtenberg reported that choline injections in rabbits produce sterility or lessened fertility, analogous to the effects of $\mathrm{x}$-ray or thorium $\mathrm{X}$, which was followed by Werner and Asher, reporting blood and skin changes similar to that produced by $x$-ray $(1-4)$.

The above was countered by Seckfort and Weise recently, who reported that choline injections do not produce a falling of white blood cell count (5).

Davis et al. have reported that repeated administration of choline produces a hemolytic type of anemia in both man and dogs (6).

In 1944, Davis advanced the theory that choline depresses red cell production by increasing the blood and oxygen supply to bone marrow through its vasodilator action $(7,8)$.

The present investigation was undertaken to ascertain the effects of choline on the leucocyte picture and elucidate the mechanism.

\section{METHODS}

The present study was conducted using adult, male and female, rabbits. After adequate control determination was made, $3 \mathrm{cc} / \mathrm{kg}(150 \mathrm{mg} / \mathrm{kg})$ of $5 \%$ choline chloride were administered to rabbits subcutaneously.

The total leucocyte counts were made from a free-flowing drop of blood from the marginal ear vein, and hematologic determinations werc made using the standard method. Occasional serum cholinesterase ( $\mathrm{ChE}$ ) activity detcrminations and electrophoresis were also made. The serum ChE activity was measured using the standard Warburg manometric method $(9,10)$. Electrophoresis was carried out in the Tiselius microcell with dialyzed serum in phosphate bufer at $\mathrm{pH} 7.73$, each at 0.2 ionic strength.

The experiment was conducted over 7 weeks or more.

\section{RESULTS}

1. A single subutaneous injection of choline chloride was administered and the results during the 7 day observation period following the injection of choline are as follows (Fig. 1 represents a typical experiment). 
The initial effect of choline was to cause a marked rise in the total number of lcucocyte. The peak of leucocytosis occurred from 4 to 6 hours after the administration of choline, the greatest increase was at $59 \%$ while the lowest was at $33 \%$, with the average at $43 \%$ (see Table 1).

TABLE 1. Effect of choline on the number of leucocytes of rabbits.

\begin{tabular}{|c|c|c|}
\hline $\begin{array}{l}\text { Rabbit } \\
\text { No. }\end{array}$ & $\begin{array}{l}\text { Time after } \\
\text { injection }\end{array}$ & $\begin{array}{l}\text { Leucocytes per cubic } \\
\text { millimeter of blood }\end{array}$ \\
\hline 1 & $\begin{array}{l}0 \\
6 \mathrm{~h} \\
11 \mathrm{~d}\end{array}$ & $\begin{array}{r}9,200 \\
12,300 \\
4,000\end{array}$ \\
\hline 2 & $\begin{array}{c}0 \\
6 \mathrm{~h} \\
18 \mathrm{~d}\end{array}$ & $\begin{array}{r}7,200 \\
10,800 \\
3,200\end{array}$ \\
\hline 3 & $\begin{array}{c}0 \\
6 \mathrm{~h} \\
15 \mathrm{~d}\end{array}$ & $\begin{array}{r}12,400 \\
10,000 \\
7,400\end{array}$ \\
\hline 4 & $\begin{array}{c}0 \\
5 \mathrm{~h} \\
14 \mathrm{~d}\end{array}$ & $\begin{array}{r}8,700 \\
12,300 \\
3,900\end{array}$ \\
\hline 5 & $\begin{array}{c}0 \\
6 \mathrm{~h} \\
21 \mathrm{~d}\end{array}$ & $\begin{array}{l}8,900 \\
9,400 \\
5,300\end{array}$ \\
\hline 6 & $\begin{array}{c}0 \\
4 \mathrm{~h} \\
10 \mathrm{~d}\end{array}$ & $\begin{array}{r}8,700 \\
13,900 \\
7,700\end{array}$ \\
\hline 7 & $\begin{array}{c}0 \\
5 \mathrm{~h} \\
12 \mathrm{~d}\end{array}$ & $\begin{array}{l}7,200 \\
6,400 \\
4,000\end{array}$ \\
\hline 8 & $\begin{array}{c}0 \\
6 \mathrm{~h} \\
22 \mathrm{~d}\end{array}$ & $\begin{array}{r}12,400 \\
16,600 \\
6,200\end{array}$ \\
\hline
\end{tabular}

h : hours, d : days.
This leucocytosis consisted for the most part of polynuclear leucocytes, which includes the shift to the left.

However, in one out of 8 rabbits no change occurred, and in the remaining 2 rabbits a leucopenia was evoked from the beginning. The leucocytosis persisted for several days, and was followed by a leucopenia.

Serum ChE activity receded, in all cases, following the administration of choline; the mean level of activity was at $82 \%$.

A separate experiment was undertaken to elucidate the mechanism causing leucocytosis. The leucocytosis was not observed in rabbits injected with acetylcholine, in doses of $0.15 \mathrm{mg} / \mathrm{kg}$. But similar results were obtained in the rabbits injected simultaneously with choline and $0.02 \mathrm{mg} / \mathrm{kg}$ of atropine sulfate. Futhermore, an injection of $20 \mathrm{mg} / \mathrm{kg}$ of benzylimidazoline failed to prevent this leucocytosis.

Therefore it is unlikely that the leucocytosis can be attributed to vascular, central or hormonal origins.

Results obtained during the 7 week observation period, following a single injection of choline.

In all rabbits, with one exception, the leucocyte count gradually decreased 7 days after or thereabouts following a single injection of choline.

The leucocytosis were replaced by a leucopenia which persisted for about 20 days with the greatest decrease at $57 \%$, the least at $41 \%$, and the average at $49 \%$. In two cases which showed leucopenia from the beginning, the degree of leucopenia increased progressively (see Table 1).

This leucopenia is mainly a reflection of the diminution of polynuclear elements. The return of the white blood cell counts to normal, occurred within 30-40 days. Here, no marked change was observed in the total red blood count, and no change occurred in the protein level and the electrophoretic pattern of serum, 
The return of serum ChE activity to initial level occurred somewhat later than in the decrease of leucocyte. Thereafter, in 4 cases, the activity exceeded their previous levels for 10 consecutive days or more. The average of peak of $\mathrm{ChE}$ activity was at $131 \%$ (see Fig. 1).

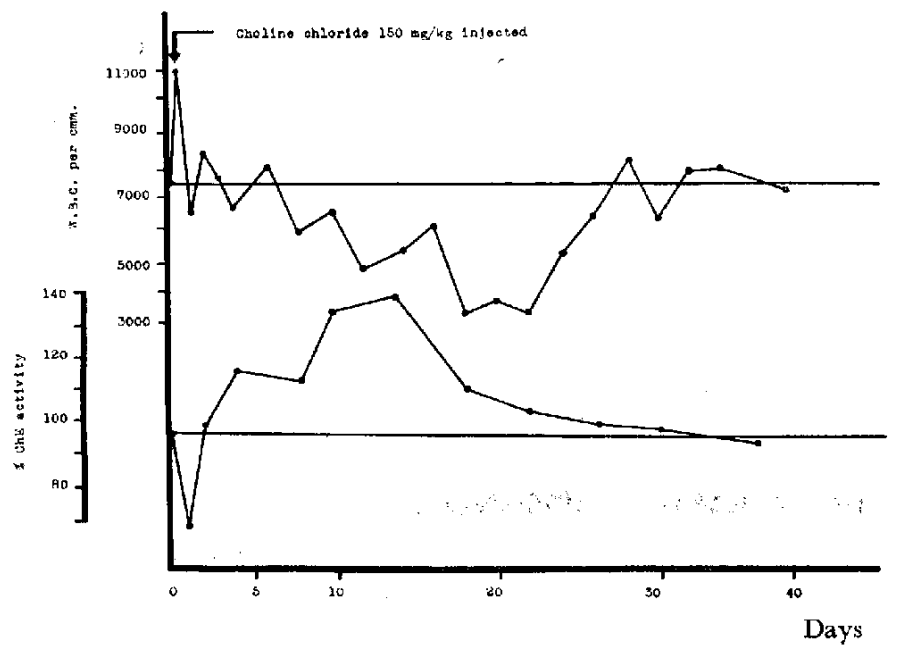

FIG. 1. Effects of choline on the leucocyte count and serum cholinesterase activity.

A certain relationship between the increase of ChE activity and the development of leucopenia seems to exist, since the leucopenia due to choline administration followed the elevation of serum ChE activity.

The next experiment was undertaken to ascertain this relationship.

In this case, "Hodstin" (an analogue of prostigmine) and diisopropyl fluorophosphate (DFP) were administered after the injection of choline. The leucopenia produced by choline was completely blocked with a daily subcutaneous injection of $0.1 \mathrm{mg} / \mathrm{kg}$ of

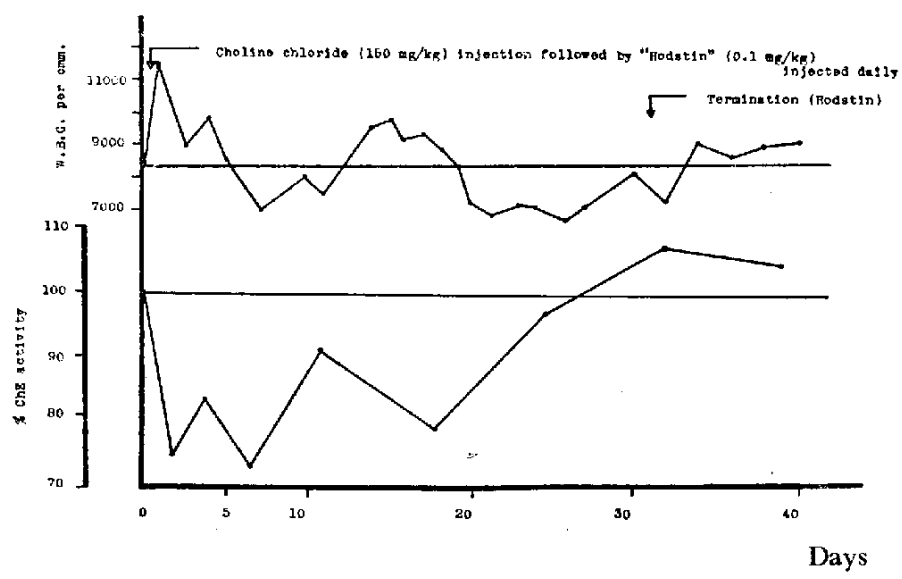

FiG. 2. Protective effects of "Hodstin" from leucopenia induced by choline. 
"Hodstin" (see Fig. 2). And similar but incompletc results were obtained in the rabbits with injections of $3 \mathrm{mg} / \mathrm{kg}$ of DFP, howcver one out of 5 rabbits showed no effect and in two out of the 5 a slight and a short-running leucopenia occurred. The repeated administration of "Hodstin" and DFP alone resulted in a reduction of ChE activity but leucocyte count remained unchanged. On the other hand, the administration of 150 $\mathrm{mg} / \mathrm{kg}$ of methionine caused leucopenia accompanied by an elevation of serum ChE activity.

II. Repetitive injecion of chline were administered with the following results.

Repeated weekly administration of $150 \mathrm{mg} / \mathrm{kg}$ of choline chloride for a period of 15 weeks, resulted in a definite and transient leucocytosis after every injection, but in a few days returned to normal level. Leucopenia did not occur during the total observation period. Serum ChE activity was observed to be inhibited for several days after every injection. However further observations did not reveal an increase above the normal level. The level of serum protein slightly increased, and the electrophoretic pattern showed a definite elevation in the albumin fraction with little change in the globulin levels which results in the increase in $A / G$ ratio.

After daily injections of $50 \mathrm{mg} / \mathrm{kg}$ of choline for 10 days running, the rabbits were autopsied, and histologic examinations were made. The essential pathological changes were as follows.

1) The general lymph nodes were medullary and swollen. 2) The mesenteric lymph apparatus was enlarged. 3) The adrenal cortex was swollen. 4) The state of marrow was red bone marrow.

Blocks of tissue were treated in 10 per cent formalin, and after cmbedding in paraffin, sections were cut. The sections were stained with hematoxylin and eosin. Histological observation of the tissues were as follows.

1) The reticulo-endothelial and Iymphatic tissues were markedly enlarged and proliferated, consisting mainly of lymphocytes with a few eosinophils.

2) The bone marrow indicated an active function of hematopoiesis.

3) No lesions were found in the testicles or the epididymis.

\section{DISCUSSION}

Subcutaneous administration of $150 \mathrm{mg} / \mathrm{kg}$ of choline chloride was accompanied by a marked leucocytosis which reached its maximum level at 4 to 6 hours. And this leucocytosis consisted for the most part of an increase in the percentage of polynuclear leucocyte including the shift to the left.

In regards to the initial effect of choline on the leucocyte, these observations disagree with the results published by Werner, and are in accord with the report of Seckfort and Weise.

This leucocytosis was not accompanied by a change of the red blood cell, and it was neither prevented by atropine nor benzylimidazoline. Such changes are obtained with methionine but can not be obtained with the acetylcholine injections alone. 
Therefore it seems unlikely that the leucocytosis can be attributed to vascular, central or hormonal origin. The mechanism causing the leucocytosis would appear to be a result of its effect on the bone marrow.

The leucocytosis were replaced by a leucopenia which persisted for about 20 days. "Hodstin" and DFP was effective in preventing the leucopenia.

Hence "Hodstin" and DFP appears to have blocked the leucopenia by preventing the rise in the ChE activity.

According to previous literature, the labil methyl deficiency caused a leucopenia (11) and ingestion of a hypolipotropic diet leads to a remarkable rise in pseudo-ChE activity in the plasma of rats. Elevated levels of plasma pseudo-ChE activity can be reduced to within the normal range by addition of lipotropic agents (12). X-irradiation and urethane reduced marrow-choline-oxidase and both $\mathrm{X}$-irradiation and urethane treatment caused leucopenia in chickens (13).

From the above, it appears that, the leucopenia due to choline administration is associated with enzymes which are related to choline metabolism especially cholinesterase and choline oxidase.

This suggested that the disturbance of choline metabolism may have been a significant factor in the leucopenic effect of choline.

Therefore it is concluded that a moderate dose of choline may activate the hematopoietic function at first, while later depressing it, probably by an interference of the metabolism of choline.

Histologic data also supports this conclusion. The effects of choline on the blood picture and serum ChE activity resemble that of a small dose of $x$-ray, therefore, it is highly probable that there is a close connection between X-irradiation and choline $(14,15)$.

\section{CONCLUSIONS}

1) Subcutaneous administration of $150 \mathrm{mg} / \mathrm{kg}$ of choline chloride to rabbit was followed by a temporary leucocytosis, after which the leacocyte commenced to decrease gradually. The maximum decrease occurred in 10 to 20 days after the injection of choline, and leucopenia continued for about 20 days.

"Hodstin" (met, oxyphenyl-trimethyl-ammonium-methylsulfate-dimethylcarbaminester) and DFP had a preventive effect upon the leucopenia due to choline.

2) Serum cholinesteiase activity was markedly reduced in the beginning, returning to normal level a few days later while a high elevation was brought about in half the number.

3) The repetition of choline injection to rabbits resulted in enlargement and swelling of general lymph nodes and adrenal cortex, and the activation of the hematopoietic function of bone marrow.

4) These changes resemble that of a small dose of x-ray. Therefore, it appears that a close connection between, X-irradiation and choline, blood cell formation and metabolism of choline, exists. 
Acknowledgment. Our thanks are due to Prof. Takeo Masaki for his kind advice and guidance during this research.

\section{REFERENSES}

1) WERNER : Münch. Med. Wschr. 15, 691 (1905)

2) SCHLACHTA: Ibid. 19, 911 (1905)

3) WERNER AND LICHTENBERG: Dtsch. Med. Wschr. 26, 22 (1906)

4) WERNER AND ASHER: Strahlentherapie 1, 442 (1912)

5) SECKFORT AND WEISE: Klin. Wschr. 29, 294 (1951)

6) Nutrition Reviewes 7, 298 (1949)

7) DAVIS : Am. J. Physiol. 142, 65 (1944)

8) DAYIS : Ibid. 142, 402 (1944)

9) AMMON: Pflügers Arch. 233, 487 (1934)

10) Levine et al.: Proc. Soc. Exper. Biol. \& Med. 73, 100 (1950)

11) DINNING et al.: J. Nutrit. 43, 525 (1951)

12) HAWKINS AND NisHIKAWARA: Biochem. J. 43, 276 (1951)

13) DinNING et al.: Proc. Soc. Exper. Biol. \& Med. 74, 776 (1950)

14) BENJAMIN et al.: Wien. Klin. Wschr. 19, 788 (1906)

15) Buchanan et al.: Am. J. Physiol. 174, 336 (1953) 